\title{
Retrospective Analysis of Six Primary Cutaneous T-cell Lymphoma Cases in the Light of Recent Advancements
}

\author{
Altı Primer Kütanöz T-Hücreli Lenfoma Olgusunun Yeni Gelişmeler \\ Işığında Retrospektif Analizi
}

(D) Betül Taş

University of Health Sciences, İstanbul Bağcılar Training and Research Hospital, Clinic of Dermatology, İstanbul, Turkey

\section{Abstract}

Objective: Primary cutaneous lymphomas (PCLs) are lymphoproliferative malignancies of skin. Although they have been confine to mycosis fungoides (MF) and Sezary syndrome over the years, the concept of PCL quite changed with the describing of new types in recent years. In our study, re-evaluation of diagnostic properties of our previously diagnosed six PCL cases was aimed, in the light of these advancements.

Method: The diagnostic features and progression of six PCL cases, which had been previously diagnosed and followed in the Dermatology clinic of Istanbul Şişli Etfal Training and Research Hospital, were retrospectively re-evaluated in the light of new advancements. For this purpose, besides their medical histories, clinical, laboratory and histopathologic findings were reviewed. In this manner, their diagnoses and clinical progressions were re-interpreted.

Results: Case 1 had been diagnosed with "Sezary syndrome" and reevaluation confirmed the diagnosis. Case 2 and 3 had been diagnosed with "lymphomatoid papulosis" and "high-grade medium/large-T-cell lymphoma", respectively. After re-evaluation, $2^{\text {nd }}$ case was thought to be more likely a high-grade CD30 (+) pleomorphic large-cell lymphoma, and 3. case a "CD30 (-) high-grade medium/large cell pleomorphic T-cell PCL." Case 4 had been diagnosed with "diffuse high grade pleomorphic mixed T and B-cell PCL". In the re-evaluation, lesions were thought to be an advanced "CD30 (+) high-grade pleomorphic large T-cell PCL that coinfiltrated with reactive B-cells". Case 5 and case 6 had been diagnosed with "MF", and "MF + follicular mucinosis (FM)", respectively. When reevaluated, $5^{\text {th }}$ case was thought to be more likely an "MF emerged from an ulceronecrotic pityriasis lichenoides et varioliformis acuta", whereas the previous diagnosis of 6 th case was confirmed again.

\section{Öz}

\begin{abstract}
Amaç: Primer kütanöz lenfomalar (PKL) derinin lenfoproliferatif maligniteleridir. Yıllarca mikozis fungoides (MF) ve Sezary sendromu ile sınırlı kalmış olan PKL kavramı, son yıllarda yeni tiplerin tanımlanması ile oldukça değişmiştir. Çalışmamızda, daha önce kliniğimizde tanı almış altı PKL olgusunun tanısal özelliklerinin, bu gelişmeler ışığında yeniden değerlendirmesi amaçlandı.
\end{abstract}

Yöntem: İstanbul Şişli Etfal Eğitim ve Araştırma Hastanesi Dermatoloji Kliniği'nde önceki yıllarda PKL tanısı konularak takip edilmiş, altı PKL olgusunun tanısal özellikleri ve progresyonları yeni gelişmeler ışı̆̆ında geriye dönük olarak değerlendirildi. Bu amaçla, olguların anamnezleri, klinik, laboratuvar ve histopatolojik bulguları tekrar gözden geçirildi. Böylelikle, hastaların önceden almış oldukları tanıları ve klinik progresyonları yeniden irdelendi.

Bulgular: Olgu 1 tipik bir "Sezary sendromu" olarak tanı almıştı ve bu tanı tekrar değerlendirmede teyit edildi. İkinci ve 3. olgular sırasıyla "lenfomatoid papülozis" ve "ileri-evre orta/büyük hücreli T-hücreli PKL" olarak tanı almışlardı. Yeniden değerlendirildiklerinde, 2.'nin daha çok ileri-evre bir "CD (+) pleomorfik büyük hücreli $P C L$ ", 3.'nün ise ileri-evre bir "orta/büyük hücreli CD (-) pleomorfik T-hücreli PKL" olabileceği düşünüldü. Dördüncü olgu "diffüz ileri evre pleomorfik mikst T ve B-hücreli PKL" olarak tanı almıştı. Tekrar değerlendirildiğinde ise lezyonların daha çok ileri-evre "reaktif B hücreleriyle ko-infiltre edilmiş, CD30 (+) pleomorfik büyük-hücreli T-hücreli PKL" ile uyumlu olduğu düşünüldü. Beşinci ve 6. olgular, sırasılyla "MF" ve "MF (+) folliküler musinozis (FM)" olarak tanı almışlardı. Tekrar değerlendirildiklerinde, 5. olgu "ülseronekrotik pitriyazis likenoides et varioliformis akuta üzerinden gelişmiş bir MF" olarak düşünülürken, 6. olgunun önceki tanısı teyit edildi.

Address for Correspondence: Betül Taş, University of Health Sciences, İstanbul Bağcılar Training and Research Hospital,

E-mail: betulavc@yahoo.com ORCID ID: orcid.org/0000-0001-5378-1478 Received: 18.02.2019 Accepted: 20.02.2019

Cite this article as: Taş B. Retrospective Analysis of Six Primary Cutaneous T-cell Lymphoma Cases in the Light of Recent Advancements. Bagcilar Med Bull 2019;4(1):25-30.

${ }^{\circledR}$ Copyright 2019 by the Health Sciences University, Bagcilar Training and Research Hospital Bagcilar Medical Bulletin published by Galenos Publishing House. 


\section{Abstract}

Conclusion: Diagnosis of a PCL with only clinical features or cellular morphology may lead a misdiagnosis. Patients should be evaluated with a multidisciplinary approach and methods, including immunophenotypic examination, DNA gene-rearrangement and, even electron microscope. It is very important to establish a close correlation between clinical findings and these examination findings to make correct diagnosis.

Keywords: Skin, lymphoma, malignant, non-Hodgkin, diagnosis, prognosis, analysis

\section{Öz}

Sonuç: PKL'lerde, tanının sadece klinik özellikler ya da hücre morfolojisine göre konulması yanıltıcı sonuçlar doğurabilir. Olgular, immünofenotipik inceleme, DNA gen yeniden düzenlenmesi ve hatta elektronmikroskopik yöntemlerin birlikte kullanımıyla, multidisipliner bir yaklaşımla değerlendirilmelidir. Klinik bulgular ve bu inceleme sonuçları arasında korelasyonun sağlanması doğru tanı için çok önemlidir.

Anahtar kelimeler: Deri, lenfoma, malignite, Hodgkin dışı, tanı, prognoz, analiz

\section{Introduction}

Lymphomas are main malignancies of lymphoreticular tissue. They are classically divided as Hodgkin and nonHodgkin lymphomas (NHL). They can be originated from nodal, or extradodal tissues (skin/mucosa) (1). Skin is the second most frequent involvement of NHLs after gastrointestinal tissue, with an incidence of 1/100.000 (2). PCLs are majority of extradonal NHL which are stemmed from skin-resident lymphocytes. They are divided by the main tumor cell population into various sub-groups, and may exhibit different clinical, histological, immunophenotypical and prognostic properties $(1,3)$. The main groups are T-cell primary cutaneous lymphomas (PCLs), B-cell PCLs, and nonclasified or provisional types, with a dominancy of the first. PCLs have been confine to mycosis fungoides (MF) and Sezary syndrome (SS) over the years. However, many new types were described owing to the recent diagnostic methods such as immunohistochemistry, T or B-cell DNA gene-rearrangement or monoclonal antibodies, and the concept of PCL has gained a new dimension with these advancements $(1,4)$. The main characteristic features of a PCL are; having only/or predominantly skin involvement, presence of a compatibility between the epidermotropism and cellular maturity, progression from local to disseminated, and progression of lymphocyte proliferation from slow (cerebriform) to rapid growth phase consistent with the loss of epidermotropism (5). On the other hand, some lymphoproliferative conditions which have previously been described as benign lymphoproliferative conditions such as "large plaque parapsoriasis", "lymphomatoid papulosis (LP)", and "follicular mucinosis (FM)" were recently described as premalignant conditions or as "a real PCL" (6-8). Contrarily, there are some misdiagnosed "pseudolyphoma" cases in literature, who were previously diagnosed as real PCLs (9). The mentioned changes in the concept of PCL, and presence of previously misdiagnosed cases in literature, encouraged us to perform this study to understand how accurately our patients were diagnosed previously.

\section{Material and Methods}

The study was conducted as a retrospective study, and was performed on previously recorded data of six PCL cases, who had been diagnosed and followed in İstanbul Şişli Etfal Training and Research Hospital, Clinic of Dermatology. After an ethical approval was obtained from local ethics committee, an informed consent was obtained from each patient, or his/her legal guardian for dead patients, to use and report their medical records for academic purposes. Study population consisted of 2 females and 4 males, between the ages of 35 and 65 years. Their recorded indivudial histories, systemic and clinical examination findings, routine hemogram biochemical/ microbiological analyses including treponema pallidum haemagglutination, venereal disease research laboratory, anti-HIV values, chest radiography, abdominopelvic ultrasonography and thoracoabdominal tomography findings in all patients, and available photographs of their lesions were checked and interpreted again. Histopathological slayds of skin and lymph node biopsies and immunohistochemically-stained slayds of skin biopsies were obtained from the archive of our pathology department. Histopathologic re-examinations of skin biopsies were made for all patients. Immunohistochemical re-examination of skin biopsies were made in case 4 and case 6, and histopathologic re-examinations of lymph node biopsies were made in case 1, 3 and case 6 , because these examinations had been performed in only these patients. Besides their previous diagnoses were reviewed, the patients' responses to administrated chemotherapies, and clinical courses of them were re-evaluated. In their medical courses, some of them had been hospitalized and followed in some different centers in certain time intervals. 
Regarding data was requested from these clinics, and was included in this study to be able to fully interpret all the courses of patients. After the entire records of the patients were collected, they were re-evaluated with the available data. Non-pathological, and non-related findings with PCL were excluded from the interpretation to avoid data crowds.

\section{Results}

A total of 6 PCL cases who consisted of 2 women and 4 men, between the ages of 35 and 65 years were evaluated. Mean age was 49 . Clinical, laboratory and histological features of patients and their courses are below;

\section{Case 1}

A 49-year-old-man was admitted to us with a complaint of extensive itchy erythema covering the entire skin, which first started 1.5 years ago. In his earlier admittions he had been diagnosed with "idiopathic erythroderma", and "generalized eczema". In the dermatological/systemic examinations, diffuse brownish-erythema, desquamation, edematous infiltration, alopecia, facies leonine, subungual hyperkeratosis, palmoplantar rhagadiform fissures, and axillar/inguinal lympadenomegaly (LAMs), were detected. In the laboratory examinations, a high leukocytosis (13.4000), high blood sedimentation rate $(40 \mathrm{~mm} / \mathrm{h})$, high lactate dehydrogenase (LDH) (698 Ü/L), and peripheral large lymphocytes with cerebriform nuclei in the rate of $40 \%$ were detected. Skin biopsy showed epidermal spongiosis and mononuclear focal lymphocytic infiltration, and linear infiltration of lymphocytes in upper reticular dermis. Nodal biopsy was consistent with dermatopathic lymphadenopathy (DPL). With the findings he was diagnosed with "SS". All the clinical and laboratory findings disappeared within 6.5 months with prednisolone + chlorambucil $(\mathrm{P}+\mathrm{CHB})$ chemotherapy. He was still in cure in the $15^{\text {th }}$ month.

\section{Case 2}

A 59-year-old-man was admitted to us with papulo-nodules on the itchy desquamative erythematous patches on the face and extremities, which were diagnosed with "LP" 2 years ago. In the dermatological/systemic examinations, $1-2 \mathrm{~cm}$ in diameters, erythematous multiple papule, plaque and nodules, high blood sedimentation rate (40 $\mathrm{mm} / \mathrm{h})$, high LDH (620U/L) were detected. Multiple skin biopsies showed similar features, which were epidermal hiperkeratosis/acanthosis, dermal patchy infiltration consisting of eosinophilic, histiocyte-like, big pleomorphic atypical cells, eosinophils, histiocytes, neutrophils and extravazed erythrocytes. Lesions were diagnosed as "LP" again, and he was began to be treated with cetirizine and topical corticosteroid. However, the lesions increased in number and size. Second skin biopsy was consistent with a "tumoral stage of MF", which showed diffuse dermal atypical lymphocytic infiltration. He was began to be treated with CHOP therapy for 5 session, however was lost due to cardiovascular insufficiency.

\section{Case 3}

A 59-year-old-man was admitted to us with itchy desquamation in his scalp, face and trunk, for 25 years. Two years ago he had been diagnosed with "earlystage-psoriasis (Ps)". In the dermatological/systemic examinations, erythemato-squamous diffuse eruption and crusted plaques in whole skin, candle grease and Auspitz signs, ungual ridging, onycholysis, subungual hyperkeratosis, high blood sedimentation rate $(55 \mathrm{~mm} /$ hg), and slight anemia were detected. Skin biopsy showed prominent epidermal parakeratosis, elongation of rete ridges, mononuclear epidermal microabcesses, spongiosis and perivascular mixed inflamatory infiltration in upper dermis, which were consistent with "eythrodermic Ps". He was began to be treated with topical corticosteroids and oral antihistamine. However, multiple nodular lesions on the face and trunk, and a severe plantar pustulosis developed within one month. Skin biopsy showed epidermal polymorphic microabcesses, and meadium/large in size, high-mitotic atypical lymphocytes in whole dermis, which were consistent with "high-grade medium/large-T-cell PCL”. Detected right inguinal lymphadenomegaly also showed high-grade lymphoma features. Although he was treated with $\mathrm{P}+\mathrm{CHB}$ combination for 3 session, and lesions were significantly regressed, the patient was lost from cardiac insufficiency.

\section{Case 4}

A 65-year-old-woman was admitted to us with itchy skin lesions arising from a diffuse erythema, which firstly started 4 years ago. In the dermatological/systemic examinations, 0.5-7 cm in diameters, violaceous and desquamative multiple lenticular papules/nodules and on the face, hands, and lower extremities, and bilaterally axillar LAMs were detected. Blood sedimentation rate was $92 \mathrm{~mm} / \mathrm{h}$. Skin biopsy showed atypical immature/pleomorphic lymphocyte infiltration showing intense mitosis in the epidermis of papules, whereas throughout the whole skin in the nodules. All types of lesions were equally stained 
with CD45RO and CD20 immunohistochemistries. With the findings the patient was diagnosed with "diffuse highgrade pleomorphic mixed T and B-cell PCL”. Because a slight regression was obtained in the lesions with $\mathrm{P}+\mathrm{CHB}$ chemoterapy, the patient was recommended for CHOP therapy in the third month, but she did not accept it. Ten months later the lesions increased further.

\section{Case 5}

A 58-year-old woman was admitted to us with a complaint of wounds in her scalp and whole skin, which had begun since 2 years, as recurrent lenticular small squamous papules. They had previously been diagnosed as "chronic superficial dermatitis" and "MF plaque stage". In the dermatological, histologic and systemic examinations, 0.5$6 \mathrm{~cm}$ in diameters, multiple, violaceous-brownish, painful, hemorrhagic and exudative plaques and ulcers covered by white and brown/black necrotic crusts, epidermal necrosis, lymphocytic exocytosis, epidermal atypical cells showing big and hyperchromatic nuclei, spinal dyskeratosis, basal hydrophic degeneration, extensive dermal perivascular lymphoplasmocytic infiltration, keratoconjunctivitis sicca, hematuria and axillar LAPs were detected. Blood sedimentation rate was $115 \mathrm{~mm} / \mathrm{h}$. There was a slight hypoalbuminemia $(3.1 \mathrm{gr} / \mathrm{dL})$ and high fever $\left(38^{\circ} \mathrm{C}\right)$. She was diagnosed with "MF" and began to be treated with $\mathrm{P}+\mathrm{CHB}$ chemoterapy. Because lesions continued to progress, therapy was changed to CHOP therapy. During this period she was lost due to respiratory insufficiency and hypotensive shock associated with high-fever, abdominal pain, myalgia, and hematuria.

\section{Case 6}

A 35-year-old man was admitted to us with a complaint of itchy wounds. They had been begun as only one $5-6 \mathrm{~cm}$ plaque, and then increased in number within 5 years. In the dermatological/systemic examinations; multiple (higher than $10 \%$ of body surface area), $2-10 \mathrm{~cm}$ in diameters, red-violaceous, scaling patch/plaques, and disseminated follicular papules in whole skin, multiple cervical and inguinal LAMs, and 2\% atypical cerebriform lymphocytes in the peripheral blood were detected. Skin biopsy showed acanthosis, hyperkeratosis, parakeratosis, light spongiosis, focal infiltration of atypical lymphocytes in epidermis, whereas a perivascular patchy atypical lymphocyte infiltration in the papillar/upper reticular dermis, and perifollicular mucinous degeneration in the lower reticular dermis. Lesions were positive for CD45RO, and negative for CD20 and CD 30 immunohistochemistries, and were diagnosed with "MF + FM" Nodal biopsy was considered in consistent with MF. Clinical stage was considered as IIA (T2N2M0B0). He was administered two sessions of CHOP chemotherapy, but did not respond. The lesions began to be more pruritic.

\section{Discussion}

SS is erythrodermic and leukemic variant of MF. There is three stage of it such as presezary, sezary and T-cell leukemia. In the first stage, an erythrodermia showing chronic dermatitis histopathology is seen. The number of peripheral atypical lymphocytes is under $1000 / \mathrm{mm} 3$. It can be difficult to diagnose during this period $(1,3,4)$ The findings of our first case in his first admittion, were complied with presezary-stage. In the SS stage, skin thickness increases and diffuse melanoerythrodermia, desquamation, edematous infiltration, alopecia, facies leonine, subungual hyperkeratosis, palmoplantar fissures and severe prruritus occur. Histopathology is variable. Epidermotropism may change, and usually perivascular band-like mononuclear lymphocytic infiltration occur. Nodal biopsy is usually complied with DPL, leucocytosis is between 10.000 and 30.000 , and the percent of atypical peripheral lymphocytes is $15-30 \%$ (it is usually higher than $50 \%$ in leukemic-stage). LDH shows degree of leukemic activation and prognosis $(3,4,10)$. Low-dose $\mathrm{P}+\mathrm{CH}$ therapy is usually leads long-term remissions in this stage (11). All findings and course of our 1 . case were consistent with typical SS-stage. On the other hand, LP is rithmic, paradoxal papular/small-nodular or papulonecrotic eruption, which shows benign clinical course but malignant histopathology, and may develop before or after MF, or accompany it $(4,12)$. Lesions' histology may be various. Patchy and wedgestyle perivascular lymphocytes, bigger-pleomorphic cells occur in type-A, whereas they are smaller and similar to MF cells in type-B $(4,13)$. However, similar views may be seen in a high-grade CD30 (+) large-cell PCL, or CD30 (-) pleomorphic PCL $(4,12,14)$. For these reasons, although the clinicopathological findings of our 2th case had thought to be consecutively developed patchy-MF, LP-plaque (type-A) and finally tumoral LP or MF, the exact diagnosis has remained in suspense because an immunostaining had not been performed. In the re-evaluation, we thought that $2^{\text {th }}$ case was more likely to be a high-grade CD30 (+) pleomorphic large-cell PCL, due to its histologic similarities and aggressive course. Lesions of our $3^{\text {th }}$ case had begun as Ps-like eruption. Early stages of both Ps and T-cell-PCLs may share common clinicopathological findings such as erythemato-squamous eruption, parakeratosis, acanthosis, 
slight spongiosis, perivascular mononuclear infiltration and slight exocytosis $(15,16)$. On the other hand, CD30 (-) high-grade medium/large cell pleomorphic T-cell PCLs are recently described lymphomas with a poor prognosis. Moreover, a palmoplantar-MF may show similar features to Ps, such as hyperkeratosis, verrucous or pustular-Ps like hyperplasia. Wakelin et al. (17) reported a CD30 (-) highgrade medium/large cell pleomorphic T-cell PCL arised from pre-existing palmoplantar Ps. These lymphomas needs for radiotherapy or polychemotheapy $(4,18)$. Furthermore, few reports regarding a PCL development on pre-existed chronic dermatoses have been reported. However, no any scientific evidence has been reported that whether such cases reflect a malignant transformation, or de-nova formation (19). After re-eavulation, he was thought to be more likely a "high-grade CD30 (-)medium/large cell pleomorphic T-cell PCL”. Although the available findings of our case strongly supported aforementioned literature, we could not be sure of our exact diagnosis due to the lack of immunostaining. Our $4^{\text {th }}$ case had been diagnosed with a "diffuse high grade mixed T and B-cell PCL". Although T and B-cell PCLs cannot exactly be distinguished without immunostaining, some indicators can help to diagnosis. T-cell PCLs are more symmetric, isolated or unified papul/ plaque/nodules which are usually covered by squames/ crusts, and show stage-compatible histopathology, whereas B-cell PCLs are usually smooth-surfaced, figured nodul/plaques which show follicular or full-thickness histopathologic features, early bone marrow involvement, and faster progress (20). Our different lesions equally stained for $\mathrm{T}$ and B-cells. These condition can be explain with the concepts of "composite lymphoma (togetherness of two lymphoma originating two different lymphocyte types)" $(20,21)$, or "co-infiltration [togetherness of a singletype lymphocyte originated lymphoma ( $\mathrm{T}$ or $\mathrm{B}$ ), and accompanying benign reactive infiltration with other type lymphocytes]" (21). Moreover, no any staining for CD30 had been performed for the lesions of case 4 , because there was no any PCL-classification including pleomorphic ones when she had been first diagnosed. When the case was re-evaluated together with all the findings and lesions' moderate response to P + CHB chemotherapy, the lesions were thought to be more likely an advanced "CD30 (+) high-grade pleomorphic large T-cell PCL, that co-infiltrated with reactive benign B-cells". Lesions of $5^{\text {th }}$ case had begun as non prutitic, chronic, recurrent, pink to red, lenticular, squamous papules, which had not been proved histologically. Later, they were quickly transformed ulceronecrotic plaques. Histopathology showed epidermal/ dermal aytpical pleomorphic lymphocytes, accompanying severeulceronecrotic/vasculitic changes, and basalvacuolar degeneration, which latter ones were not compatible with a classical MF, but closely compatible with an ulceronecrotic pityriasis lichenoides et varioliformis acuta (PLEVA). PLEVA is a small-papulonecrotic and hemorrhagic, chronic skin eruption, which can rarely progress to large plaques. Sometimes high-fever, myalgia, astenia, weakness and hemorrhagic crusted ulcers may accompany it (22). Progression of a PLEVA to PCL is not usual condition. However, Forstan et al. (23) have reported that their two patients and other some PCL cases, which their lesions developed from pre-existed PLEVA lesions. Moreover, T-cell infiltration or clonality rarely can occure in PLEVA, so it was hypothesized that a PCL may develop from PLEVA lesions, when elimination capacity of immune system is exceeded $(23,24)$. Thus, it was thought that development of these lesions was not consistent with just a conventionalMF, but was with an "MF emerged from an ulceronecrotic PLEVA", both clinically and histopathologically. Also, the reason of patient's death was thought more likely caused by intraabdominal hemorrhagies due to progressive vasculitic changes. Our $6^{\text {th }}$ case had been diagnosed with "MF + FM". FM is characterized pruritic, follicular, prominent papules, which is caused by perifollicular mucinous degeneration. It is considered as a poor prognostic factor when it accompany Hodgkin lymphomas (25). Clinically, the lesions were compatible with patch/plaque stages of MF + disseminated FM. Skin involvement was higher than $10 \%$, and peripheral atypical lymphoctes were lower than $5 \%$. Lesions were positively stained for CD45RO, but not for CD20 and 30 . Although nodal biopsy was complied with DPL, they were considered as involved in lymphoma, because the presence of multiple palpable nodes and prominent germinal center enlargements. Although the lesions were considered in low-stage of MF [IIA (T2N2M0B0)] according to "TNMB classification" for MF and SS (26), their unresponsiveness to administered CHOP sessions was thought to be related with accompanied FM. When the lesions were re-eavulated, previous diagnoses of them were confirmed. Additionally, it was thought that an accompanying FM may lead worse prognosis in MF cases.

\section{Conclusions}

PCLs are cutaneous malignancies composed of various subtypes, and there is no homogenization in these tumors. Each PCL case may have a distinctive attitude. Diagnosis of a PCL with only clinical or histopathologic findings may lead a misdiagnosis. Therefore, PCL cases should 
be evaluated with a multidisciplinary approach, and, immunophenotyping, DNA gene-rearrangement, and even electronmicroscopy. Establishing close correlation between the clinical and other examination findings is very important to make correct diagnosis.

\section{Acknowledgement}

I thank Professor Dr. İlknur Kıvanç Altunay for her valuable contributions

\section{Ethics}

Ethics Committee Approval: The study was approved by the İstanbul Şişli Etfal Training and Research Hospital Local Ethics Committee (approval no: ŞEH/96-49/017).

Informed Consent: A written informed consent was obtained from each patient or their legal guardian.

Peer-review: Externally peer-reviewed.

Conflict of Interest: No conflict of interest was declared by the authors.

Financial Disclosure: The authors declared that this study received no financial support.

\section{References}

1. Burg G, Dommann S, Dummer R. Malignant lymphomas of the skin. Ther Umsch 1993;50:828-834.

2. Akay BN. Classification in cutaneous lymphomas. Türkiye Klinikleri J Dermatol-Special Topics 2014;7:1-5

3. Pimpinelli N, Santucci M, Giannotti B. Cutaneous lymphoma: a clinically relevant classification. Int J Dermatol 1993;32:695-700.

4. Williemze R, Beljeaards RC, Meijer CJ. Classification of primer cutaneous T-cell lymphomas. Histopahology 1994;24:405-415.

5. Edelson RL. Cutaneous T-cell lymphoma: mycosis fungoides, Sezary syndrome and other variants. J Am Acad Dermato 1980;2:89-106.

6. Zelickson BD, Peters MS, Muller SA, Thibodeau SN, Lust JA, Quam LM, Pittelkow MR. T-cell receptor gene rearrangement analysis: cutaneous T-cell lymphoma, peripheral T-cell lymphoma, and premalignant and benign cutaneous lymphoproliferative disorders. J Am Acad Dermatol 1991;25:787-796.

7. Black MM, Jones EW.”Lymphomatoid" pityriasis lichenoides; a variant with histological features simulating a lymphoma: A clinical and histopathological study of 15 cases with details of long term follow up. Br J Dermatol 1972;86:329-347.

8. Samman PD. The natural history of parapsoriasis en plaques (chronic superficial dermatitis) and prereticulotic poikiloderma. Br J Dermatol 1972;87:405-411.
9. Tian Z, Shiyu Z, Tao W, Li L, Yuehua L, Hongzhong J. Lymphoma or pseudolymphoma: A report of six cases and review of the literature. Dermatol Ther 2018:e12807.

10. Shapiro PE, Pinto FJ. The histologic spectrum of mycosis fungoides/sezary syndrome (cutaneous T cell lymphoma) A review of 222 biopsies including newly described patterns and the earliest pathologic changes. Am J Surg Pathol 1994;18:645-667.

11. Holloway KB, Flowers FP, Ramos-Caro FA. Therapeutic alternatives in Cutaneous T cell lymphoma. J Am Acad Dermatol 1992;27:367378.

12. Kadin ME. Common activated helper-T-cell origin for lymphomatoid papulosis, mycosis fungoides and some types of Hodgkin's disease. Lancet 1985;19;2:864-865.

13. Black MM."Classical"lymphomatoid papulosis. A variant of pityriasis lichenoides. Am J Dermatopathol 1981;3:175-176.

14. Karp DL, Horn DT. Lymphomatoid papulosis. J Am Acad Dermatol 1994;30:379-395.

15. Nicolis GD, Stratigos JD, Tosca AD, Capetanakis JA. Mycosis fungoides with verrucous lesions. Acta Dermatovenereol 1979;59:80-82.

16. Verga M, Braverman IM. The use of immunohistologic analysis in differentiating cutaneous T-cell lymphoma from psoriasis and dermatitis. Arch Dermatol 1991;127:1503-1510.

17. Fink-Puches R, Soyer HP, Kerl H. Febrile ulceronecrotic pityriasis lichenoides et varioliformis acuta. J Am Acad Dermatol 1994;30:261-263.

18. Forston JS, Schroeter AL, Esterly NB. Cutaneous T-cell lymphoma (parapsoriasis en plaque). An association with pityriasis lichenoides et varioliformis acuta. Arch Dermatol 1990;126:14491453.

19. Kikuchi A, Naka W, Harada T, Sakuraoka K, Harada R, Nishikawa T. Parapsoriasis en plaques: its potential for progression to malignant lymphoma. J Am Acad Dermatol 1993;29:419-422.

20. Wakelin SH, Salisbury j, Smith NF. Primary cutaneous pleomorphic $\mathrm{T}$ cell lymphoma arising pustular psoriasis. Br J Dermatol 1994;131(Suppl.44):57-62.

21. Williemze R. New concepts in the classification of cutaneous lymphomas. Arch Dermatol 1995;131:1077-1080.

22. Lambert WC. Premycotic eruptions. Dermatol Clin 1985;3:629645

23. Arai E, Sakurai M, Nakayama H, Morinaga S, Katayama I. Primary cutaneous T-cell-rich B-cell lymphoma. Br J Dermatol 1993;129:196-200.

24. Yagi H, Ogai M, Izumi T, Ebihara T, Sugiura M, Tokura Y, Takigawa M. Cutaneous T-cell lymphoma with massive co-infiltration of polyclonal B cells. Br J Dermatol 1994;130:26-230.

25. Goldenhersh MA, Zlotogorski A, Rosenmann E. Follicular mycosis fungoides. Am J Dermatopathol 1994;16:52-55.

26. Onsun N. Erdemoglu Y. Updated classification and staging cutaneous lymphoma. Turkderm 2010;44:178-179. 